\title{
Water mass characteristics and associated fauna of a recently discovered Lophelia pertusa (Scleractinia: Anthozoa) reef in Greenlandic waters
}

Kenchington, Ellen; Yashayaev, Igor; Tendal, Ole Secher; Jørgensbye, Helle

Published in:

Polar Biology

Link to article, DOI:

10.1007/s00300-016-1957-3

Publication date:

2017

Document Version

Publisher's PDF, also known as Version of record

Link back to DTU Orbit

Citation (APA):

Kenchington, E., Yashayaev, I., Tendal, O. S., \& Jørgensbye, H. (2017). Water mass characteristics and associated fauna of a recently discovered Lophelia pertusa (Scleractinia: Anthozoa) reef in Greenlandic waters. Polar Biology, 40(2), 321-337. https://doi.org/10.1007/s00300-016-1957-3

\section{General rights}

Copyright and moral rights for the publications made accessible in the public portal are retained by the authors and/or other copyright owners and it is a condition of accessing publications that users recognise and abide by the legal requirements associated with these rights.

- Users may download and print one copy of any publication from the public portal for the purpose of private study or research.

- You may not further distribute the material or use it for any profit-making activity or commercial gain

- You may freely distribute the URL identifying the publication in the public portal 


\title{
Water mass characteristics and associated fauna of a recently discovered Lophelia pertusa (Scleractinia: Anthozoa) reef in Greenlandic waters
}

\author{
Ellen Kenchington $^{1} \cdot$ Igor Yashayaev $^{1} \cdot$ Ole Secher Tendal $^{2} \cdot$ Helle Jørgensbye $^{3}$
}

Received: 15 April 2015/Revised: 18 January 2016/ Accepted: 28 April 2016

(C) The Author(s) 2016. This article is published with open access at Springerlink.com

\begin{abstract}
The first living sample of Lophelia pertusa from Greenlandic waters was inadvertently collected at $60.3675^{\circ}$, $-48.45528^{\circ}$, entangled together with other corals to a seawater sampler and property sensor (CTD) package. We collected in situ photographs taken at two sites in the same area in order to determine whether a reef was present. We identified reef-like structures formed by living and dead L. pertusa at $886-932 \mathrm{~m}$ depth on a steep slope. We assembled and analyzed hydrographic data to characterize the reef environment in order to facilitate future localization of other reefs and predictions of the impacts of climate change. We showed that the reef was located in a layer of modified Atlantic Water of relatively stable bottom temperature $\left(4.1-5.0^{\circ} \mathrm{C}\right)$ and salinity $(34.90-34.98)$ with density slightly higher $\left(27.62-27.71 \mathrm{~kg} \mathrm{~m}^{-3}\right)$ than that reported for the occurrence of reefs in the northeast Atlantic, and in an area with exceptionally and persistently high currents of $>15 \mathrm{~cm} \mathrm{~s}^{-1}$ at $1000 \mathrm{~m}$. The intermediatedepth salinity maximum was found in the depth range where the corals were found. We discovered signals of consistent vertical and horizontal transports at 700-900 m over the reef area. Although this area is not directly
\end{abstract}

Electronic supplementary material The online version of this article (doi:10.1007/s00300-016-1957-3) contains supplementary material, which is available to authorized users.

Ellen Kenchington

Ellen.Kenchington@dfo-mpo.gc.ca

1 Department of Fisheries and Oceans, Bedford Institute of Oceanography, Dartmouth, Canada

2 Natural History Museum of Denmark, Copenhagen, Denmark

3 Section for Marine Living Resources, Technical University of Denmark, Charlottenlund, Denmark influenced by intermediate and deep convection in the Labrador Sea, the seasonal evolution of near-bottom temperature, salinity and density for the 700-900 m depth range revealed strong seasonal patterns with both temperature and salinity reducing to their annual minimal values at the end of March and staying low for 1 month with an indication of a second minimum in June, 3 months later. The occurrence and temporal extent of these minima likely arose through a combination of local convection from the surface and advection of cooled and freshened waters at depth from the Irminger Sea. A diversified associated fauna was described; the short list of species compiled from our limited sample comprised species common in the area, as well as rare species, species new to Greenland, and species new to science.

Keywords Cold-water coral · Greenland · Lophelia pertusa . Associated fauna Atlantic Water - Irminger Current $\cdot$ Deep water seasonality

\section{Introduction}

Ahermatypic scleractinian corals, both solitary and colonial, are known from most regions of the world oceans, many of them from deep cold-water habitats (Zibrowius 1980). Lophelia pertusa is the best known among the reefforming deepwater species, with a wealth of publications existing on various aspects of its distribution and ecology (partly reviewed in Rogers 1999; Freiwald et al. 2004; Rogers et al. 2007; Sulak et al. 2007; Davies et al. 2008). Lophelia pertusa can form cohesive reefs or reef fields (aggregations of smaller reefs), with or without bioherms (build-up of organic matter under the reef structure), but also occurs as isolated colonies. The most extensive known 
reef field is $40 \mathrm{~km}$ long and $5 \mathrm{~km}$ wide, located off Røst Island of the Lofoten archipelago, Norway (Fosså and Alvsvåg 2003) where it is associated with Norwegian Coastal Water and Atlantic Water along the Norwegian margin (Dullo et al. 2008). Large reefs can be hundreds to thousands of years old (Schröder-Ritzrau et al. 2005) and constitute biogenic habitats, which support ecosystems comprising hundreds of associated species from nearly all phylae (Rogers 1999).

Lophelia pertusa is widely distributed in the Atlantic Ocean, mainly to the north. It has been found also in the Indian and the Pacific Oceans although the records there are few in number (Freiwald et al. 2004; Buhl-Mortensen et al. 2014). In the northern Atlantic, L. pertusa has been recorded numerous times in two major areas. One stretches from northern Norway along the continental slope southwards to off western Africa and westwards along the Scotland-Greenland Ridge over the Faroes to southern Iceland and the mid-Atlantic Ridge (Copley et al. 1996; ICES 2008; Buhl-Mortensen et al. 2014). The other stretches along the American continental slope from Nova Scotia to Florida and into the Gulf of Mexico and the Caribbean Sea (ICES 2008). The two areas are well separated by deep-sea basins and great distances, with few occurrences on seamounts (Rogers et al. 2007), raising speculation on the likelihood and means of genetic interchange. The recent discovery of L. pertusa from Greenlandic waters, made in 2012 (Tendal et al. 2013), has created an important extension to the biogeographic range of this species by narrowing the geographical gap between eastern and western Atlantic L. pertusa populations.

Dullo et al. (2008) examined the relationship between L. pertusa reefs and hydrology in the northeast Atlantic. They found that the coral reefs on the Celtic and Nordic margins were confined to temperature and salinity fields bounded by a density envelope between 27.35 and $27.65 \mathrm{~kg} \mathrm{~m}^{-3}$. Off southwest Greenland in the locality of the L. pertusa discovery, the hydrographic characteristics of the water masses, including their seasonal and interannual variability, have not been examined previously at a level sufficient for assessing the environmental conditions under which the species is living and for making connections to the hydrographic conditions over the L. pertusa reefs elsewhere; however, the general oceanographic setting of the region has been well documented. The coastal and shallow waters from the southwestern tip of Greenland from Cape Farewell northwards are influenced by a system of strong currents encompassing Greenland and flowing in the same direction (Yashayaev 2007). The West Greenland Current receives the cold and relatively low saline Polar Water from the East Greenland Current and passes it via Davis Strait into Baffin Bay or around the northern Labrador Sea into the waters flowing south and southeast along the Canadian Labrador shelf and slope. Outside the Greenland shelf break, $500 \mathrm{~m}$ and deeper, there is a relatively warm and saline core of Atlantic Water. This water is carried there by the Irminger Current, which is often associated or even combined with the West Greenland Current, but other than being partly and locally linked and sharing the same general direction, these flows have different origin, composition and location of their cores relative to the shelf break (e.g., Yashayaev 2007; Yashayaev et al. 2007). Dullo et al. (2008) associate the occurrence of L. pertusa in the northeast Atlantic with Atlantic Water, which is being carried to the Nordic Seas by various branches of the North Atlantic Current (Yashayaev and Seidov 2015). One of its branches forms the Irminger Current that takes warm saline water toward the Labrador Sea. Near Greenland, the Polar Water of the East Greenland Current actively mixes with the Atlantic Water delivered there by the Irminger Current, with this process being enhanced by strong shear at the interface of the two water masses and winter-time cooling and vertical mixing (convection). The products of their mixing, containing the signatures of both, subduct down the slope off the shelf break where the new record of L. pertusa was found. The Polar Water is found close to the coast, and the Atlantic Water is found as a 500- to 800-m-thick layer over the continental slope with a core at about 200-300 m depth (Yashayaev 2007). The Polar Water in particular has been warming significantly, causing changes to circulation in Baffin Bay (Myers and Ribergaard 2013); in southwest Greenlandic waters, the depth of the core gradually decreases from southeast to northwest, whereas the depth gradually increases from south to north to below $400 \mathrm{~m}$ in the northern Davis Strait and Baffin Bay (Ribergaard 2012). Below the Irminger Current $(>500 \mathrm{~m})$, the water over the slope remains warm and saline, but is derived through a somewhat different route of modification - this is the Icelandic Slope Water, hereafter ISW, that is formed through mixing of Atlantic Waters and the fresher and colder waters from the Icelandic shelf and slope (Yashayaev et al. 2007), which in turn are linked to the waters coming from the Nordic Sea. L. pertusa reefs in the northeast Atlantic are associated with Eastern North Atlantic Water (ENAW) in the intermediate layer along the Celtic margin (Dullo et al. 2008). Both ISW and ENAW originate from the same source and have a distinct hightemperature/low-salinity signature, but ISW, as it enters the Labrador Sea, reflects a longer transformation (modification) history and is the warmest and saltiest water in the entire 500-1500 m depth range of the Labrador Sea. However, it is notably cooler and fresher that ENAW due to mixing with cooler and fresher water masses encountered along the ISW pathway and winter vertical mixing along the southwestern Greenland slope. This pathway is 
the most likely means of long-distance connectivity between $L$. pertusa reefs in the northeast Atlantic.

Here, we report new details of the ecology and living conditions of the first find of L. pertusa from Greenlandic waters made in 2012 (Fig. 1; Tendal et al. 2013). We elaborate on the oceanographic setting and describe an initial list of associated fauna ascertained from study of the original specimen and new in situ photographic images.

\section{Materials and methods}

\section{Physical oceanography}

Fisheries and Oceans, Canada (DFO) conducts annual monitoring (1990 to present) along a transect running from Hamilton Bank on the Labrador Shelf $\left(53.667^{\circ},-55.5^{\circ}\right)$ to Cape Desolation on the Greenland Shelf $\left(60.5^{\circ},-48.25^{\circ}\right)$ under the Labrador Sea Monitoring Program. This line is the Atlantic Repeat Hydrography Line 7 West (AR7 W) of the 1990-2002 World Ocean Circulation Experiment and presently forms the core component of the Canadian Atlantic Zone Off-Shelf Monitoring Program (AZOMP). The discovery of $L$. pertusa was inadvertent. A single fragment of a living colony (Fig. 2) associated with large specimens of the gorgonian corals Paragorgia arborea and Primnoa resedaeformis (Online Resource 1) was entangled on the top of the conductivity-temperature-depth (CTD) package as it surfaced at one of the fixed stations on the AR7W line off Greenland, during the annual AZOMP survey in June of 2012. The location of the discovery was $60.3675^{\circ},-48.45528^{\circ}$ (Fig. 1).

Vertical CTD profile data collected in the vicinity of the Greenland slope within the water depth range of 300-2000 m were collated. These data (temperate, salinity and density) were compiled from the NOAA NODC World Ocean Dataset, from the AZOMP surveys and from profiling Argo floats (Yashayaev and Loder 2009; Keike and Yashayaev 2015). Density was calculated as sigma-theta as in Dullo et al. (2008). We used data collected between 1990 and 2015. Profiles that reached within $200 \mathrm{~m}$ of gridded bottom topography and that followed the continental slope at bottom depths of 300-1920 m $(N=242$; yellow points in Fig. 1) were used to characterize the reef environment. A slightly larger data set including the first data set but expanded to the surrounding waters to depths of $2000 \mathrm{~m}$ (122 additional points from 1940-2000 m; red points in Fig. 1), and also only using profiles that reached within $200 \mathrm{~m}$ of gridded bottom topography, was used to create temperature-salinity $(T-S)$ profiles $(N=364$; yellow and red points in Fig. 1). Lastly, all profiles from the vicinity of the reef that had valid data for selected depth strata were used to evaluate annual and seasonal variability in temperature, salinity and density at depth $(N=901$; all data including additional blue points in Fig. 1). In that dataset, profiles that were much deeper in their full extent were used, but only to the depth range of interest (i.e., 300-2000 m) so as to characterize the water surrounding the reef away from the slope. This was necessary in order to accurately reflect the local environment as the area had very steep depth contours and may be near a canyon (Fig. 1). Those latter data were detrended either by season or by year following the method introduced in Yashayaev and Zveryaev (2001) to separately examine the main effects in detail. Detrending was performed using an 8th degree least-square polynomial fit. Temperature and salinity-depth frequency diagrams normalized by the total number of points in each depth band for each 40-m interval were used to show the most probable water temperature with depth.

The spatial pattern of deep currents at approximately $1000 \mathrm{~m}$ depth in the study area was determined from Argo float trajectories compiled over a 13-year period from 2001 to 2013 (Yashayaev and Loder 2009; Keike and Yashayaev 2015). The individual float displacements were summed up in $0.5^{\circ}$ geographic coordinate cells. Each cell accounts crossings by floats even if data transmission occurred outside that cell.

\section{In situ photographs}

A second survey took place on October 4, 2012, during a DFO-led international multidisciplinary cruise operating in the Davis Strait area. In situ photographs were taken from each of two drift transects in the area where the L. pertusa specimen was collected (CON134 and CON135 being 1.6 and $1.3 \mathrm{~km}$, respectively; Fig. 3) using the Natural Resources Canada (NRCAN) digital still camera system referred to as the $4 \mathrm{KCam}$. This system is capable to $4000 \mathrm{~m}$ depth, and houses a Canon Rebel Eos Ti 12 megapixel camera and two Canon flashes enclosed inside an aluminum roll cage. The area covered by the field of view of each photograph when the camera is landed squarely on the sea floor is $0.47 \pm 0.05 \mathrm{~m}^{2}$ (mean $\pm \mathrm{SD}$ ) (Beazley et al. 2013). Temperature and depth were measured with a Sea-Bird Electronics SBE 39 recorder attached to the $4 \mathrm{KCam}$. It can be deployed at depths up to $3500 \mathrm{~m}$, and the accuracy of the temperature reading is $\pm 0.002{ }^{\circ} \mathrm{C}$. The position of the camera was determined using an ORE Trackpoint 3 USBL Tracking System (ORE Offshore, 4 Little Brook Road, West Wareham, MA 02576 USA), which is a high-accuracy survey quality acoustic navigation system.

The nonconductor hydrostatic wire of the camera was used to lower it via a winch to the sea bed where it hovered near bottom; the winch operator then lowered the camera 
Fig. 1 Position of CTD profiles from 300 to $2000 \mathrm{~m}$ collected from 1990 to 2015 used to summarize temperature, salinity and density in the vicinity of the Lophelia pertusa reef (green star). Yellow symbols represent data positions from the continental slope $(N=242)$; red symbols represent data positions from an expanded spatial range used to construct $T-S$ profiles $(N=364)$ (both of these data sets used only profiles that reached within $200 \mathrm{~m}$ of gridded bottom topography and were shot over depths equal to or shallower than $2000 \mathrm{~m}$ ); blue symbols represent data positions used to characterize the local environment of the reef $(N=901)$ and included valid data positions used in analyses of selected strata (100-200 m, ...) regardless of whether the profile reached the bottom and also included profiles that in their full extent may have exceeded $2000 \mathrm{~m}$

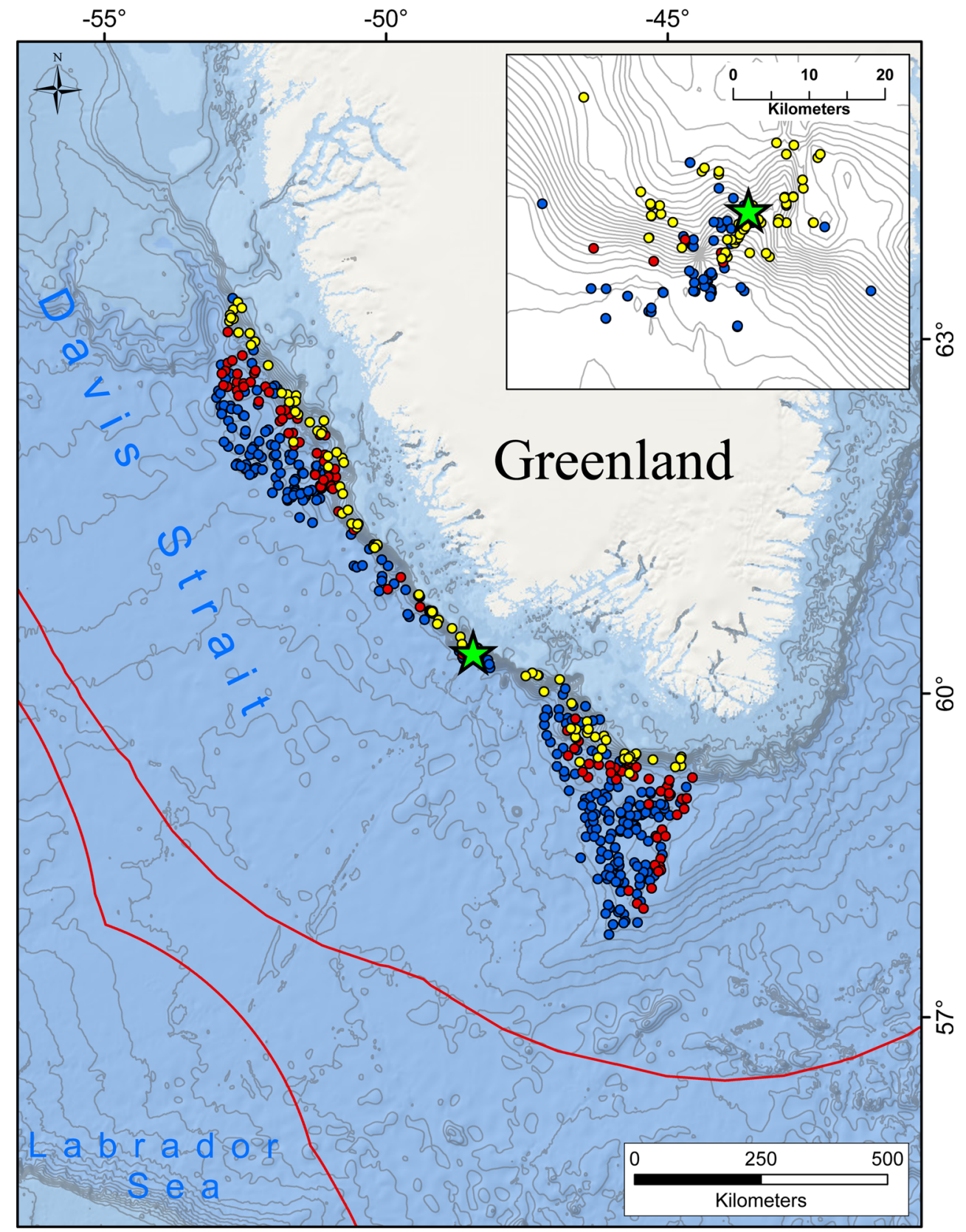

causing an attached lead weight to touch the bottom triggering the camera and flashes. The winch operator then raised the camera off the sea bed allowing it to drift with the ship. It was then lowered again after approximately $1 \mathrm{~min}$. This continued until the minimum transect length of $1 \mathrm{~km}$ was achieved as monitored by the ship's position.

The 4KCam was used to take the first in situ images of the reef. Accurate depth of each photograph was obtained by cross-referencing the time stamp on the camera with that of the Sea-Bird recorder, and position was similarly determined by cross-referencing with the Trackpoint 3 data.

\section{Fauna associated with specimen}

The single large sample (Fig. 2) of L. pertusa, collected in March 2012, was frozen and later dried, while some small fragments were preserved in alcohol. Before drying, the coral block was carefully photographed from all angles, and loose and easily picked associated fauna was sampled separately and stored in alcohol. It was decided not to break the specimen and so the associated fauna could only be sampled superficially. Further associated fauna with hard skeletons was picked from the dried sample. Identification of the associated fauna was done by specialists on 

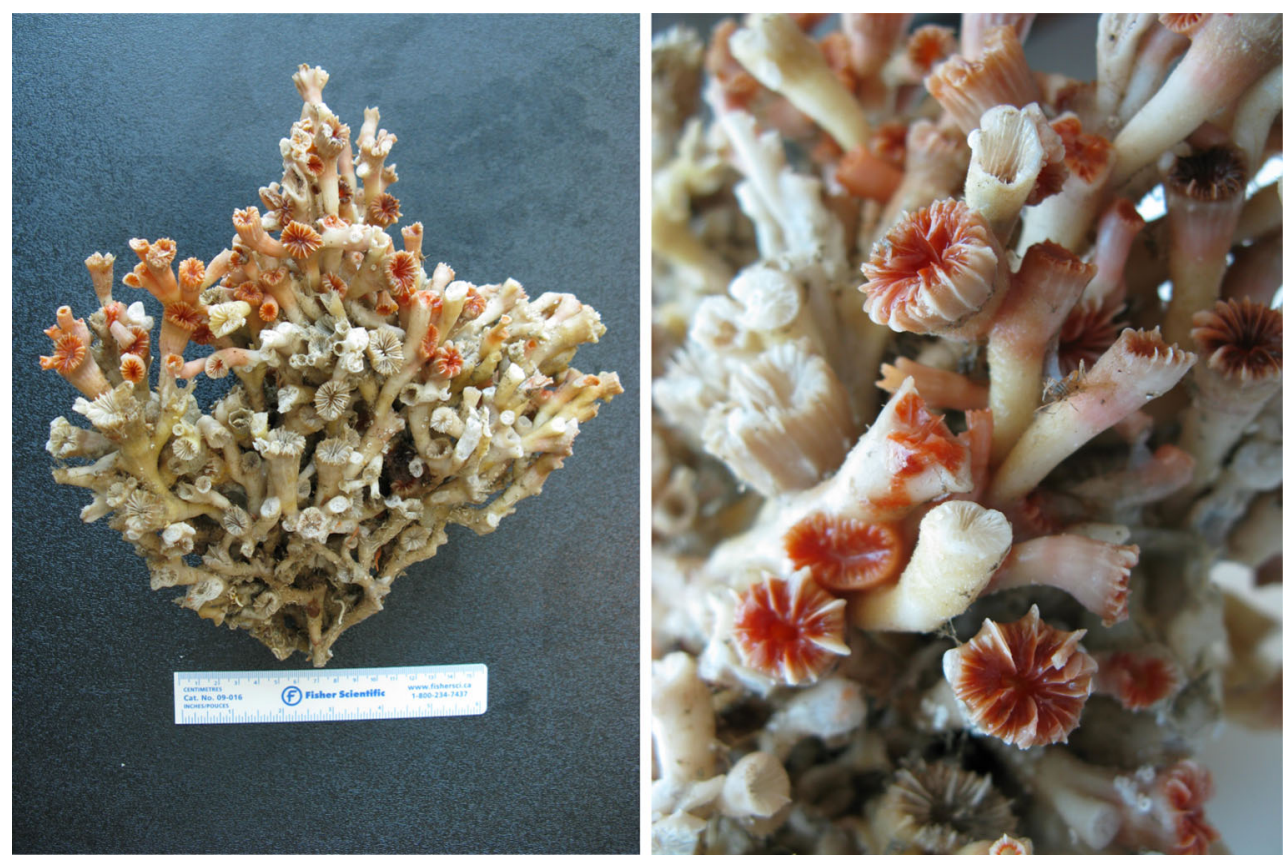

Fig. 2 Photograph of the live Lophelia pertusa colony taken on board the deck of the CCGS Martha L. Black in March 2012. Left panel whole colony with $15.5 \mathrm{~cm}$ ruler as a scale guide; Right panel close-up of the colony tips

the respective taxa. The sample was included in the Cnidarian collection of the Natural History Museum of Denmark, University of Copenhagen. Details on the associated species distribution in Greenland waters were taken from T. Schiøtte and O. S. Tendal (eds., unpublished: Report on Greenland marine benthic animals, diversity and geographic distribution, project funded by the Danish Environment Agency, Arctic Environment Programme) in order to place the findings into context with the regional fauna.

\section{Results}

\section{Physical description of the area}

Data collected from the vicinity of the L. pertusa collection site (Fig. 1) coincided with an area of systematically high temperature $\left(4.13-5.03{ }^{\circ} \mathrm{C}\right.$ ) and salinity (34.90-34.98) (Fig. 4), which is the known signature of the Atlantic Water and its modifications. Water density was between 27.62 and 27.71 (Fig. 4). In December, the data are spread through the full range of the variables (Fig. 4). The range of variability shown in the temperature-salinity $(T-S)$ plots was particularly wide in the upper layer as expected due to the presence of both Atlantic and Polar Waters and significantly narrowed below $800 \mathrm{~m}$. When viewed by year, there is a strong warming trend in the $T-S$ plots (Fig. 5) with warmer and more saline water appearing in recent years.
There was a strong seasonal cycle through the water column that was most pronounced in temperature (Fig. 6). The temperature minimum was observed at the end of winter to early spring (March-April), right at the end of the cooling season or weeks following it (Fig. 6), suggesting that water was vertically mixed locally through winter-time convection and penetrated to the bottom or stopped not far from it. This mixing will ventilate the environment while the water stays fairly warm-although slightly cooled as a result of vertical/convective mixing, it was still $4.5^{\circ} \mathrm{C}$ in winter, providing oxygen, nutrients and chlorophyll (that are known to peak following winter mixing). In June, there was a second dip in temperature below $600 \mathrm{~m}$ (Figs. 6 and 7) that was paralleled in salinity (Fig. 7, 700-900 m), creating colder fresher water at depth (Fig. 7, 700-900 m). This is cold intermediate water that was horizontally transported (it did not appear in the upper layers) possibly coming from as far as Cape Farewell where tip-jet wind is known to cause cooling (Moore and Renfrew 2005). The time required for the water to travel from the southern tip of Greenland to the site at the speed of $5-10 \mathrm{~cm} \mathrm{~s}^{-1}$ was consistent with this conclusion (Yashayaev and Seidov 2015). The water properties in the vicinity of the L. pertusa are summarized in Fig. 7. At this depth, there has been strong inter-annual change as well as seasonal variability. However, the range of seasonal variation is similar to the inter-annual variation, putting the latter into perspective (Fig. 7).

Inter-annual variation in temperature was more pronounced in the deeper waters than at the surface with 


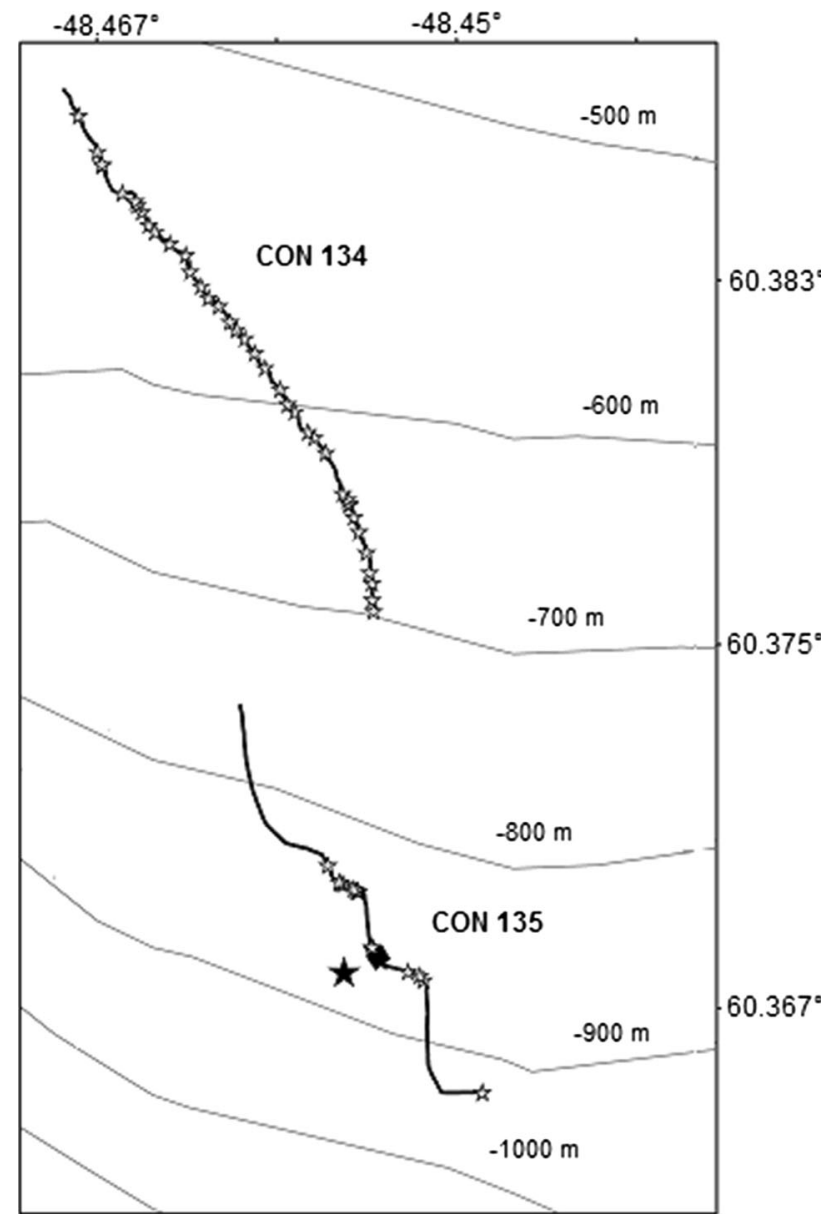

Fig. 3 Locations of the two 4KCam drift transects and photographs (stars) taken in October 2012 in the vicinity of the Lophelia pertusa reef. The location of the CTD cast which discovered the live $L$. pertusa colony is indicated by the single large black star. Depth contours were derived from the General Bathymetric Chart of the Oceans (GEBCO) 08 Grid bathymetry and are only approximate

average temperature varying within a degree over the time period (Fig. 8). In the 1990s, the water over the reef area was colder (Fig. 8) and fresher (not shown) than in recent decades. Despite annual and inter-annual changes, both temperature and salinity at $600 \mathrm{~m}$ and deeper appeared very stable and consistently high throughout the record (Fig. 9), which is likely associated with continual feed of water of Atlantic origin, ISW in particular.

The displacements between consecutive positions of individual Argo floats from a 13-year period, between 2001 and 2013, provided a detailed view of mid-depth $(\sim 1000 \mathrm{~m})$ circulation around the southern tip of Greenland (Fig. 10). The resulting velocity fields revealed the intensified boundary current along the continental slope and recirculation of this water toward the Irminger Sea. The current at the location of the $L$. pertusa reef was remarkably strong $\left(10-15 \mathrm{~cm} \mathrm{~s}^{-1}\right.$ ) and persistent (standard errors much smaller than mean currents).

\section{Photographic survey}

The topography of the photographic transect was dominated by the very steep continental slope, and it was not possible for the vessel sounder to make a clear picture of the slope area. The current was very strong, and the camera was nearly lost due to entanglement. Pictures were obtained in the depth interval from 670 to $1047 \mathrm{~m}$ ascertained through matching the time stamp on the photographs with that of the depth reading from the Sea-Bird recorder. A total of 96 photographs were taken, of these 36 were without information, 20 contained some information and 40 photographs were considered good (containing information in approximately $50 \%$ or more of the image). The rough and steep nature of the slope made the interval between photographs rather arbitrary, ranging from 0 to $59 \mathrm{~m}$. The average temperature recorded from the Sea-Bird recorder attached to the camera housing was $4.86{ }^{\circ} \mathrm{C}$ with a minimum temperature of $4.83{ }^{\circ} \mathrm{C}$ and a maximum of $4.92{ }^{\circ} \mathrm{C}$. Those temperatures were consistent with those of the separately collected CTD profiles analyzed above (Fig. 4).

Live $L$. pertusa colonies forming a reef-like structure (Fig. 11) were observed at 4 locations on one camera transect (CON135; Fig. 3) at depths of 911, 922, 931 and $932 \mathrm{~m}$. Dead $L$. pertusa were noted at two other locations along the same transect, at 886 and $907 \mathrm{~m}$, respectively. The habitat surrounding the reef was dominated by sponges and other corals (Fig. 11). L. pertusa colonies were not seen in photographs from the second transect, CON134 (Fig. 3).

The reefs had the form of rounded, protruding structures with extensive development of the interior dead parts and with living $L$. pertusa on the crust. They seemed to reach sizes of at least $1 \mathrm{~m}$, consistent with the presence of a bioherm.

\section{Biological data}

The single sample obtained was a $25-\mathrm{cm}$ large fragment from the surface of a $L$. pertusa colony (Fig. 2). One side was covered by numerous $(>100)$ living, light reddish polyps (Fig. 2). They were of different diameters with all stages being represented, from initial intra-tentacular buds to separated small polyps still recognizable as daughter polyps, and further to fully grown polyps. In some parts of the sample, up to five daughter polyps were distinguished. Below the layer of living polyps, branches of the colony were well developed carrying calices from dead polyps and had open spaces of different sizes between the branches (Fig. 2).

Fauna associated with the fragment was found mainly on and in the dead lower parts of the specimen. More than 30 species belonging to the phyla Porifera, Cnidaria, Annelida, Mollusca, Crustacea, Bryozoa and Echinodermata were found (Table 1). Boring sponges were not found. 

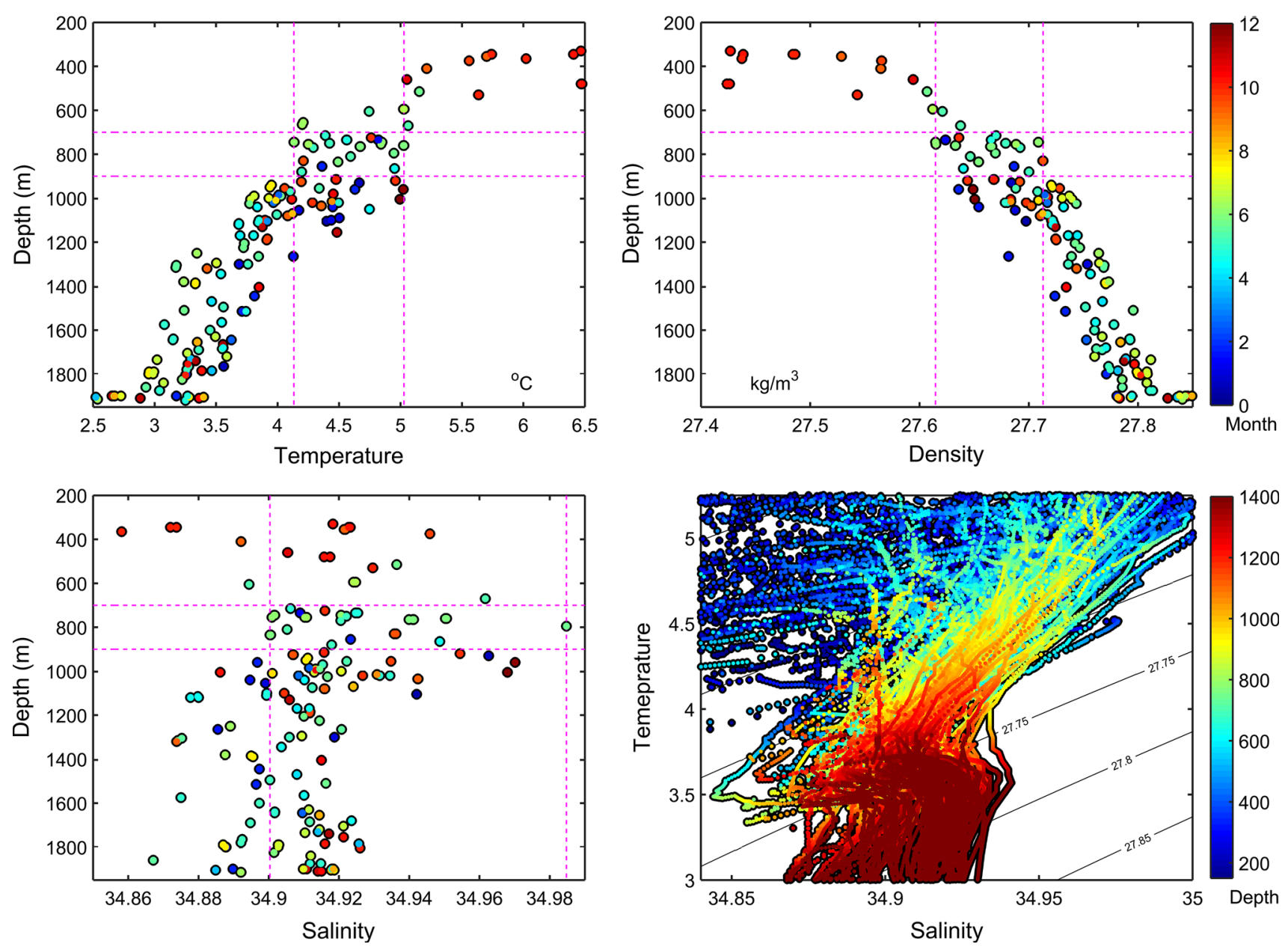

Fig. 4 Scatterplots of temperature $\left({ }^{\circ} \mathrm{C}\right)$, density (sigma; $\left.\mathrm{kg} \mathrm{m}^{-3}\right)$ and salinity by depth and color-coded by season. The depth range of the $L$. pertusa reef is outlined, and the range of values for each variable at that depth is shown. The relationship between temperature and

salinity $(T-S)$ from 200 to $1400 \mathrm{~m}$ is shown in the bottom right panel color-coded by depth (m). Data were drawn from the local environment of the L. pertusa reef $(T-S$ plot: red symbols in Fig. 1; all others: yellow symbols in Fig. 1)

Associated fauna viewed in the photographs could not be identified to species with the same degree of certainty. Some species such as the gorgonian corals Paragorgia arborea and Primnoa resedaeformis (Fig. 11, Online Resource 1) were identified by their morphology and their known distribution; however, identification of the sponges required an examination of their spicules which was not possible without specimens. Only one sponge species was identified with confidence. Therefore, only those megafauna that could be identified with some degree of certainty were reported here (Table 1).

\section{Annotated species list of associated fauna}

Foraminifera Several species of calcareous Foraminifera were found on the dead branches. No attempt was made to identify them.

Porifera The hexactinellid Asconema setubalense was seen in several in situ photographs; it is known from the

area. Forcepia forcipis was the best represented of the species attached to the specimen. On the photographs of the fresh sample, it was seen as a porous sponge filling many of the spaces between the branches (Fig. 2); it was new to the Greenland fauna. Iophon piceum was identified and is also a well-known sponge from the area. The Hymedesmia species were thinly growing and very little material was found when dried; there were enough spicules of each to recognize them as different species, but not for a final identification-18 species of the genus being known from Greenland waters. In comparison, there are $>25$ species of Porifera reported from Norwegian reefs (Burdon-Jones and Tambs-Lyche 1960; Mortensen and Fosså 2006), >65 species from Swedish reefs (Alander 1942; Tendal unpublished), 95 species from Rockall Bank (van Soest and Lavaleye 2005) and $>35$ species from Faroese reefs (Jensen and Frederiksen 1992; Tendal unpublished).

Boring sponges were not found in the sample and have not been recorded previously from Greenland waters. As 

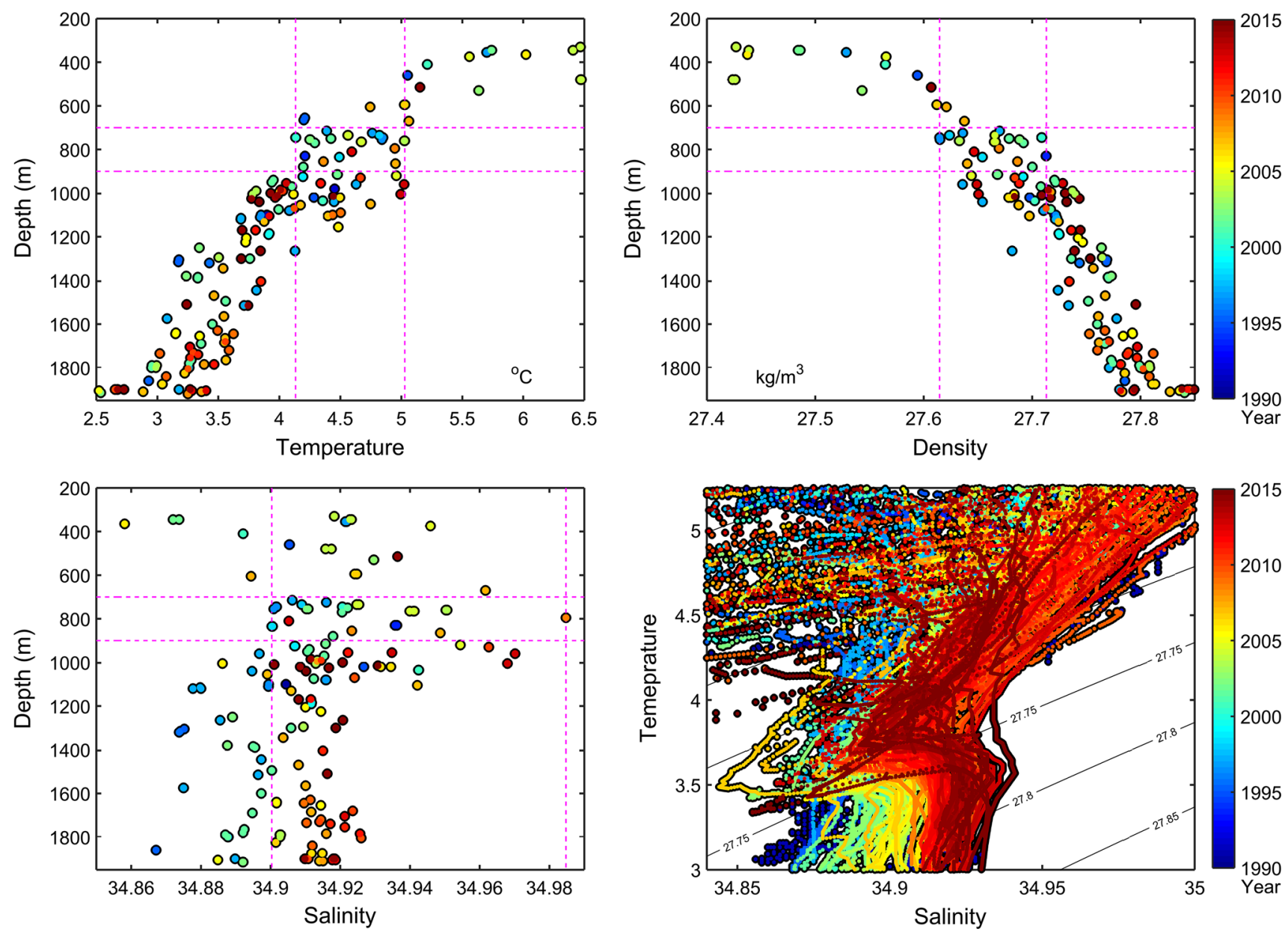

Fig. 5 Scatterplots of temperature $\left({ }^{\circ} \mathrm{C}\right)$, density (sigma; $\mathrm{kg} \mathrm{m}^{-3}$ ) and salinity by depth and color-coded by year. The depth range of the $L$. pertusa reef is outlined, and the range of values for each variable at that depth is shown. The relationship between temperature and

salinity $(T-S)$ from 200 to $1400 \mathrm{~m}$ is shown in the bottom right panel color-coded by depth (m). Data were drawn from the local environment of the L. pertusa reef $(T-S$ plot: red symbols in Fig. 1; all others: yellow symbols in Fig. 1)

they are elsewhere known as the most important bioeroders of L. pertusa corals (Beuck et al. 2007; van Soest and Beglinger 2009), this means that provided the growth of the corals is not especially slow, the bioherms in Greenland may reach a substantial size in a shorter span of time than elsewhere in the distribution area.

Cnidaria Halecium labrosum and Lafoea dumosa are known from West Greenland (Schuchert 2001). The large octocorals $P$. resedaeformis and $P$. arborea are both known from the area (Madsen 1944; Jørgensen et al. 2013; Tendal et al. 2013; Buhl-Mortensen et al. 2014). While $P$. resedaeformis has been known for many years from West Greenland fjords (Jungersen 1915), this is not the case with $P$. arborea. Despite being large (Greenland specimens become $2 \mathrm{~m}$ wide) and readily identified, it was not recorded by the early major Danish expeditions working in West Greenland, viz. "Ingolf" 1895-1896, "Tjalfe" 1908-1909 and "Godthaab" 1928, the first find being from 1967 (Tendal 1992). In comparison, 32 species of hydroids

and 7 species of octocorals were identified from Norwegian reefs (Burdon-Jones and Tambs-Lyche 1960; Mortensen and Fosså 2006), and 15 and 2, respectively, from Faroese reefs (Jensen and Frederiksen 1992; Tendal unpublished).

Annelida Polychaetes were represented by fragments that were only identified to Family; at least 5 species were present. In comparison, 28 species are known from Norwegian (Burdon-Jones and Tambs-Lyche 1960) and 72 from Faroese (Jensen and Frederiksen 1992) reefs. Eunice norvegica, which is generally found in L. pertusa reefs (Mueller et al. 2013) and regarded as an indirect reef builder, was not recorded, and the species is not known from Greenland.

Mollusca The gastropod Mohnia simplex is rare in Greenland, being found only once before.

Crustacea Janira maculosa is known from West Greenland. Caprella rinki has only been taken once before, on the type locality in South Greenland (Stephensen 1933). Gitana cf. rostrata was new to Greenland, provided the 

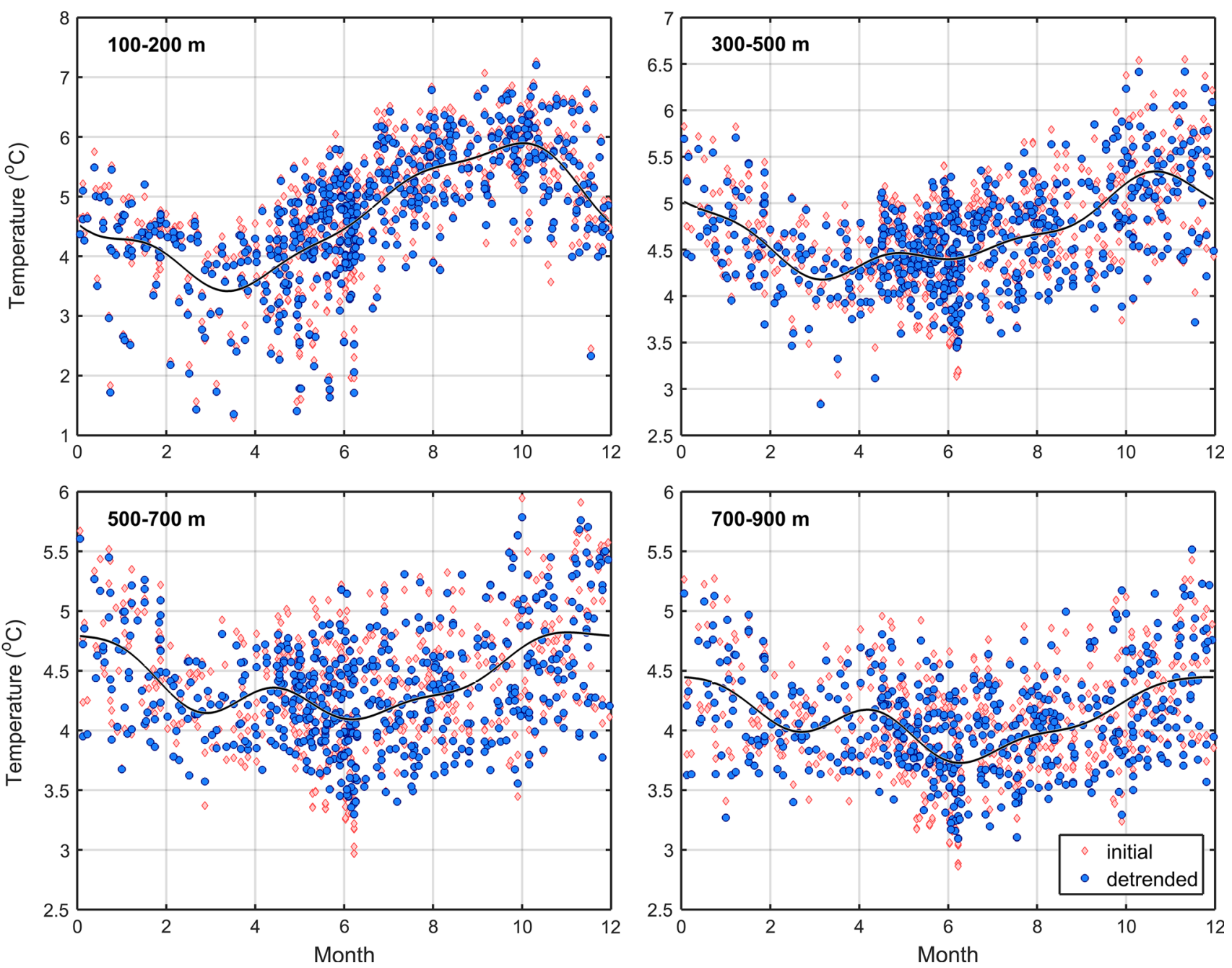

Fig. 6 Detrended (using 8th degree least-square polynomial fit) seasonal variation in temperature values for four depth categories/ layers. Data were drawn from the local environment of the Lophelia

pertusa reef (blue symbols in Fig. 1). Red symbols represent original data; blue symbols represent detrended data

identification is correct. In comparison, 14 species of isopods and 8 species of amphipods were identified from Norwegian (Burdon-Jones and Tambs-Lyche 1960; Mortensen and Fosså 2006), and 13 and 10, respectively, from Faroese (Jensen and Frederiksen 1992) reefs.

Bryozoa Reteporella beaniana, Disporella hispida, Entalophoroecia deflexa and Tubulipora aperta were all known from West Greenland, the last mentioned with some doubt about the identification (Bille Hansen 1962). Exidmonea atlantica and Turbicellepora boreale were both new to the Greenland fauna. Turbicellepora bathyalis and $T$. groenlandica were both new to science (Denisenko 2016). In comparison, 40 species were identified from Norwegian (Burdon-Jones and Tambs-Lyche 1960; Mortensen and Fosså 2006) and 45 from Faroese (Jensen and Frederiksen 1992) reefs.

Echinodermata Specimens of a Gorgonocephalus were seen on some photographs. Further identification was not

possible, four species having been reported from Greenland. Ophiactis abyssicola and Ophiacantha anomala were known from Greenland. In comparison, 15 species of ophiuroids were identified from Norwegian (BurdonJones and Tambs-Lyche 1960; Mortensen and Fosså 2006) and 8 from Faroese (Jensen and Frederiksen 1992) reefs.

\section{Discussion}

\section{Physical oceanographic setting of the reef and possible biogeographic affinities}

The discovery of a living $L$. pertusa reef off southwest Greenland at approximately $900 \mathrm{~m}$ depth provided an important biogeographic record by extending the known distribution in the North Atlantic considerably to the 

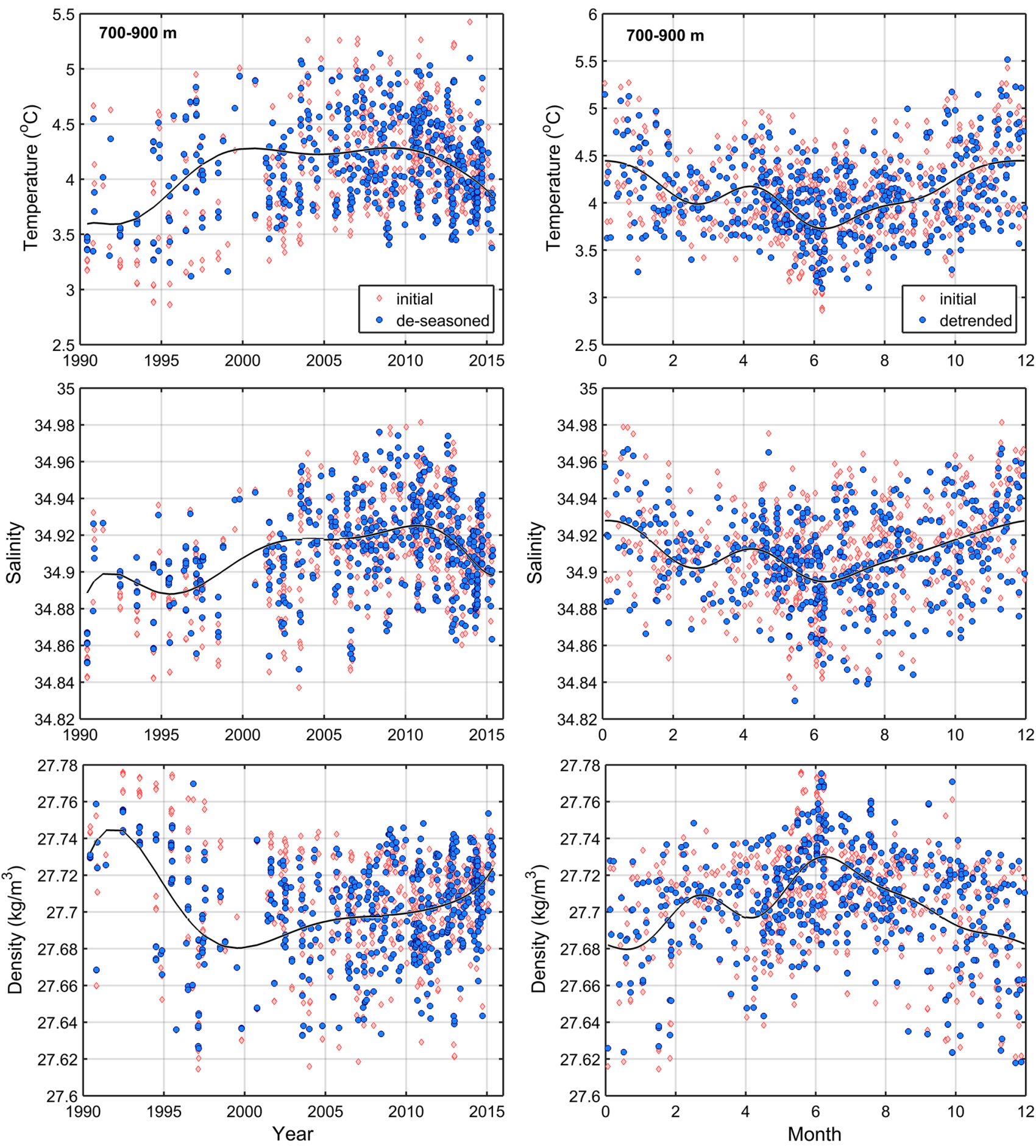

Fig. 7 Scatterplots of original and detrended (through the polynomial fitting) seasonal variation (left panels) and inter-annual variation before and after subtraction of the regular seasonal cycle (right panels) in temperature $\left({ }^{\circ} \mathrm{C}\right)$, density (sigma; $\mathrm{kg} \mathrm{m}^{-3}$ ) and salinity for

northwest. This depth was slightly deeper than the range of 700-850 m reported for living $L$. pertusa along the shelves of the Porcupine and Rockall Banks in the northeast Atlantic (Dullo et al. 2008). The large apparent height of the bioherms suggested that the reef is of ancient origin and

the 700-900 $\mathrm{m}$ depth stratum. Data were drawn from the local environment of the Lophelia pertusa reef (blue symbols in Fig. 1). Red symbols represent original data; blue symbols represent detrended data

has likely persisted due to its depth and placement along a steep slope below the depths of iceberg rafting. The East Greenland Current brings icebergs calved from the glaciers in East Greenland around Cape Farewell to the southwest coast off Greenland in the vicinity of the reef. These were 

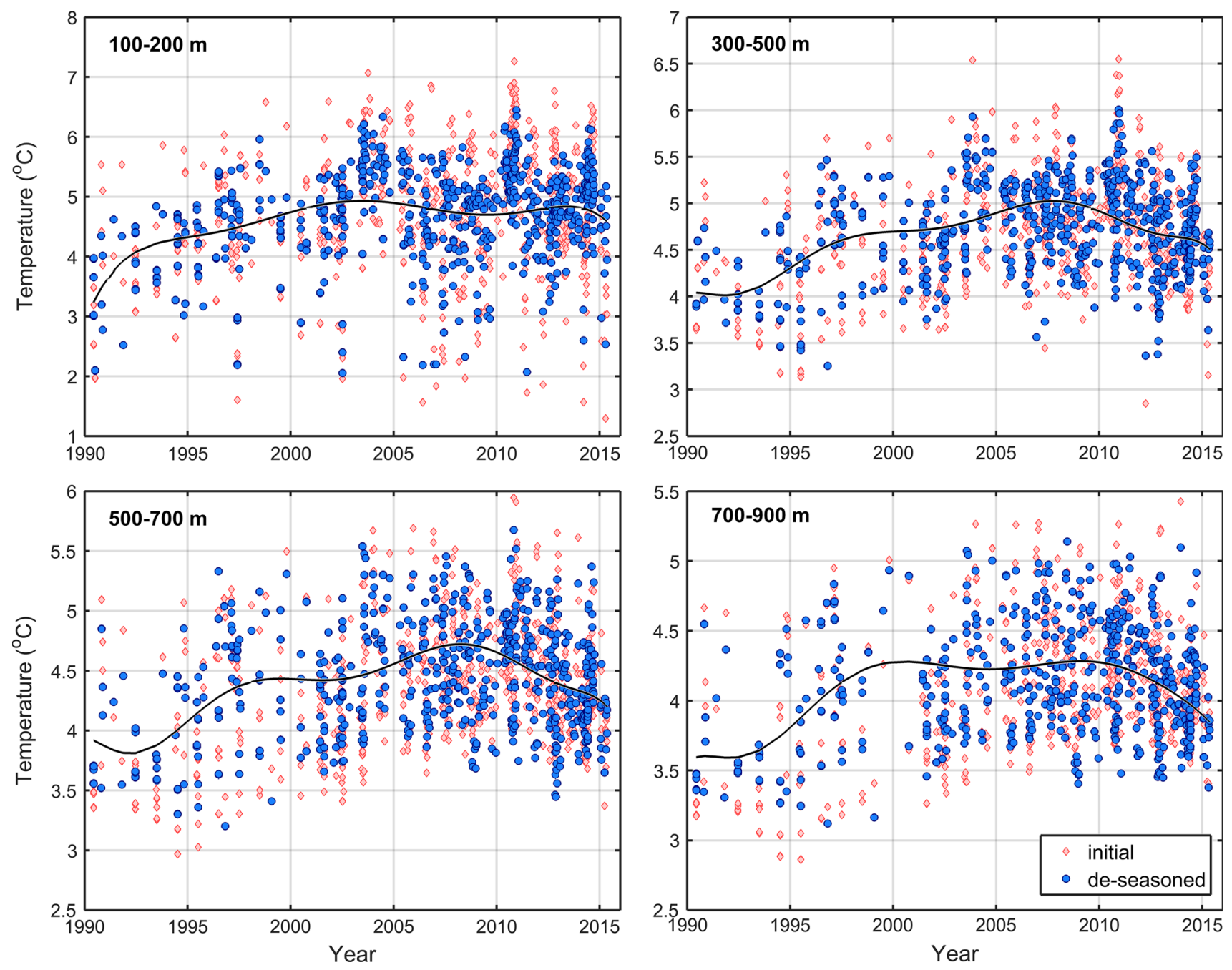

Fig. 8 Inter-annual variation in temperature values for four depth layers before and after subtraction of the regular seasonal cycle. Data were drawn from the local environment of the Lophelia pertusa reef

unlikely to scour the reef as the average keel depth (submerged depth) of the icebergs was only around 60-80 m and the maximum is $<150 \mathrm{~m}$ (Mangor and Zorn 1983). However, paleoiceberg keel depths could have been considerably deeper and depths of $950 \mathrm{~m}$ have been described from Disko Bay, central West Greenland (Kuijpers et al. 2007). Identification of ancient scour marks in the vicinity of the reef could help to determine its age.

Our oceanographic data allowed for comparisons of water mass characteristics between the location of the Greenlandic reef and those found in the northeast Atlantic. In the Labrador Sea, the ISW presents a warmer and saltier counterpart of the Labrador Sea Water (LSW), both sharing the same depth and density range, and when production of LSW by winter convection (Lazier et al. 2002; Yashayaev 2007) is reduced, the ISW tends to expand filling the depth previously occupied by LSW. That mechanism may have (blue symbols in Fig. 1). Red symbols represent original data; blue symbols represent detrended data

led to the increased ISW inflow, which enters the Labrador Sea along the Greenland slope covering the depth range where the $L$. pertusa colony was found. Following the slope of Greenland into deeper water the Deep Western Boundary Current also carries water that originated from the Nordic Seas across the Denmark Strait - this water is known as the Denmark Strait Overflow Water (Yashayaev and Dickson 2008). This water lies deeper than the coral reef site and is quite young with a high saturation of dissolved gases and other features of newly ventilated waters. It may represent the lower limit of the reef. The association of the reef with the Atlantic Water (AW) layer indicated an association with reefs along the Reykjanes Ridge, i.e., of northeast Atlantic origin, and was consistent with the physical boundary conditions observed for similar reefs in the northeast Atlantic (Dullo et al. 2008). The L. pertusa reefs on the Celtic and Nordic European continental 

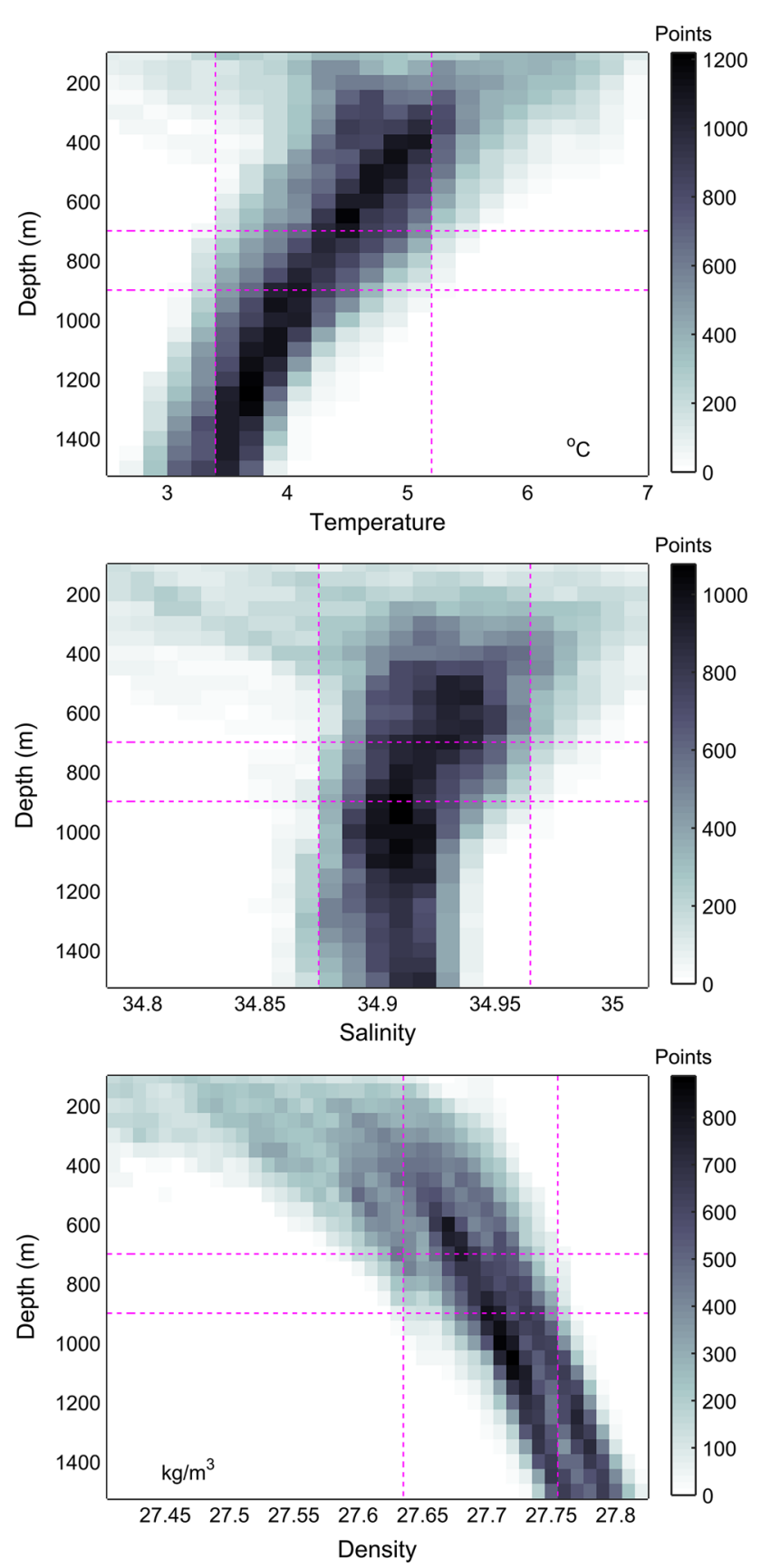

Fig. 9 Number of temperature, salinity and density observations (each profile's 5-m mean values count as individual points) in $40 \mathrm{~m}$ depth - seawater property intervals/bins. Darker areas represent greater numbers of points and reflect the most common conditions at a given depth. The depth range of the Lophelia pertusa reef is outlined

margins have an upper limit corresponding to water mass boundaries of Eastern North Atlantic and Mediterranean Outflow Water (MOW) and Norwegian Coastal Water and $\mathrm{AW}$, respectively (Dullo et al. 2008). In both areas, the lower boundary was at the Intermediate Salinity Maximum represented by the MOW on the Celtic margin and the AW on the Nordic margin. In our case, the reef resides in the layers of all-year high-temperature and salinity values. The waters above the reef may be warmer and saltier in some seasons but also show much stronger seasonal variations and excursions into colder and fresher states. It is just at the approaching of the depths of the reef that the water properties become more stable, yet the water, as we indicated about, gets ventilated quite regularly. There are at least two reasons for the density of Atlantic Water in the Labrador Sea to be higher than that of NEAW. First of all, the Atlantic Water in its circuit around the subpolar gyre exchanges heat and salt with the other resident waters, and heat diffuses faster than salt leading to more cooling than freshening and therefore to a density decrease. The other reason is convective vertical winter-time mixing that results in cooling and increasing of the density of the bottom layer.

Despite annual and inter-annual changes, both temperature and salinity at $600 \mathrm{~m}$ and deeper appeared very stable and temperature was consistently relatively high throughout the record for the area. Such stability of oceanographic conditions in a region despite complex dynamics and vigorous currents (Clarke 1984) is remarkable. The fundamental contrast in water mass properties seen at depth suggests sustained if not persistent inflow of relatively warm and saline modified Atlantic waters, which may vary in strength but not direction, providing a constant supply of these waters to the intermediate-depth layers of the Labrador Sea, mostly through ISW.

Dullo et al. (2008) concluded that $L$. pertusa was restricted to a density envelope of sigma-theta between 27.35 and $27.65 \mathrm{~kg} \mathrm{~m}^{-3}$. Our observations concurred with that finding at the lower bound where we observed $27.63 \mathrm{~kg} \mathrm{~m}^{-3}$, but extended the upper boundary to $27.75 \mathrm{~kg} \mathrm{~m}^{-3}$. However, it was clear that on both sides of the Atlantic, this species occupied the intermediate waters and that physical boundary conditions determined distributions. The physical conditions tend to adapt to various factors and processes, and the noted increase in the density of Atlantic Water between the two marginal regions is one.

One of our exciting discoveries was the signal of vertical mixing at depth in the spring. This provided a mechanism to support delivery of oxygen, nutrients and food from the surface to $1000 \mathrm{~m}$ depth where the reef was found. We presented evidence of both vertical and horizontal water transports at depth which when combined with the relatively warm Atlantic Water, provided ideal conditions for growth of benthic organisms that can be food limited in deep waters (Carney 1989, 2005).

There were no direct observations of currents available for the depth and location of the reef site. The closest moored observations were collected south of Cape Farewell (Clarke 1984) and were short in duration. However, using displacements between consecutive positions of 
Fig. 10 Water circulation at approximately $1000 \mathrm{~m}$ around Greenland derived from Argo float data of the period 2001-2013. Displacements between consecutive float positions were summed in $0.5^{\circ}$ geographic coordinate cells. Different mean strengths of current are highlighted by different colors and lengths of arrows. The location of the reef is indicated by the black oval

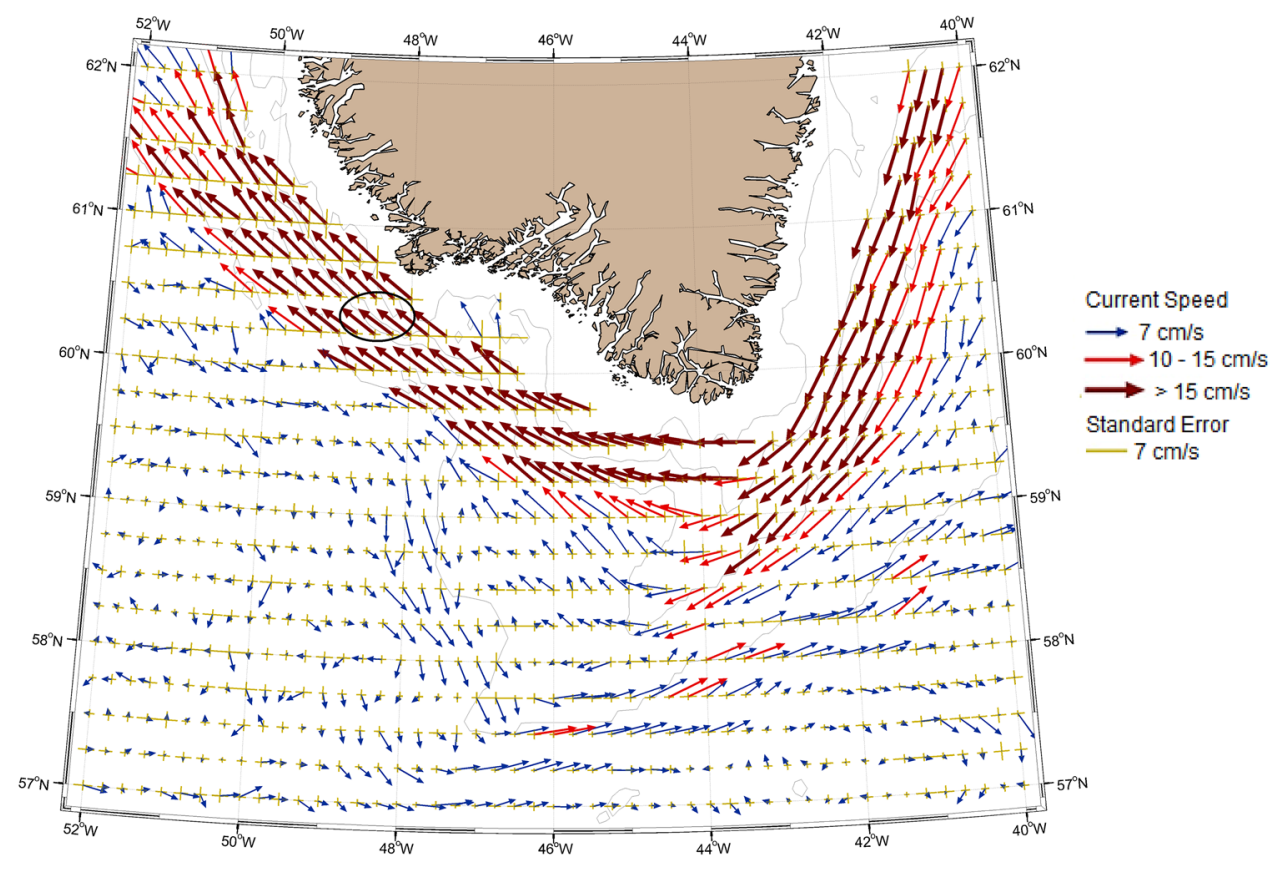

individual Argo floats we were able to construct a detailed view of mid-depth circulation around the southern tip of Greenland. The current in the vicinity of the $L$. pertusa reef at $1000 \mathrm{~m}$ is remarkably strong $\left(>15 \mathrm{~cm} \mathrm{~s}^{-1}\right.$ in some areas and $>10 \mathrm{~cm} \mathrm{~s}^{-1}$ in many) and persistent (standard errors much smaller than mean currents). These estimates support our explanation of the second seasonal temperature minimum at the depths of the reef as a signal advected from the area of extreme winter cooling associated with tip jets.

In a global analysis of the habitat associated with the occurrence of $L$. pertusa, Davies et al. (2008) identified a salinity of 35 , mean temperatures of $6.2-6.7^{\circ} \mathrm{C}$ and dissolved oxygen levels of $6.0-6.2 \mathrm{ml} \mathrm{l}^{-1}$ as the environmental niche for this species. The reef off Greenland falls within this salinity range but occurs at lower temperatures than reported elsewhere (Dodds et al. 2007; Dullo et al. 2008; Davies et al. 2008), and well below its upper thermal tolerance limit of $15^{\circ} \mathrm{C}$ (Brooke et al. 2013).

\section{Scleractinians in Greenland}

The scleractinian fauna of Greenland waters is poor. The only living species hitherto reported was the bathyal solitary Flabellum alabastrum known from numerous localities over a wide area off West Greenland (Kramp 1932; Jørgensen et al. 2013; Tendal unpublished). Dead skeleton fragments from the colony-forming Solenosmilia variabilis were taken by the Canadian CCGS Dawson in 1971 at $60.06167^{\circ},-46.825^{\circ}$ in Davis Strait from 1465 to $1555 \mathrm{~m}$ depth (Zibrowius 1980). From time to time, the occurrence of $L$. pertusa in Greenland waters has been claimed by zoologists and geologists bringing supposed fragments to the Zoological Museum (SNM, Copenhagen), but all samples checked turned out to represent either dead skeletal fragments from octocorals, or skeletons from stylasterids. A few dead skeletal fragments from $L$. pertusa were taken west of Iceland at $65.65806^{\circ},-40.91667^{\circ}$ at 341-365 m depth by the German FFS Walther Herwig in 2009 (Tendal, unpublished).

\section{The condition of the reef}

The sample seems to come from a reef with a well-developed bioherm. The living polyps are numerous, sit close and were in fine condition. Active growth was evident from the lively formation of buds. The growth rate was difficult to estimate, but because of the temperature regime it was probably in the lower end of the scale for the species. On the other hand, the size of the reef was probably stable, since degradation of the dead parts is likely slow because boring sponges do not occur in the area, and dissolution is low under the relatively cold conditions-leaving negative growth to occur through breakage of colonies under their own weight in the fast currents. It could not be judged from the photographs if the surveyed area constituted a coherent reef situated along the steep slope, or if the observed bioherms represented smaller, separate reefs.

\section{Associated fauna}

In comparison with the fauna lists obtained from $L$. pertusa reefs in Norway, the Faroe Islands and the Bay of Biscay, 

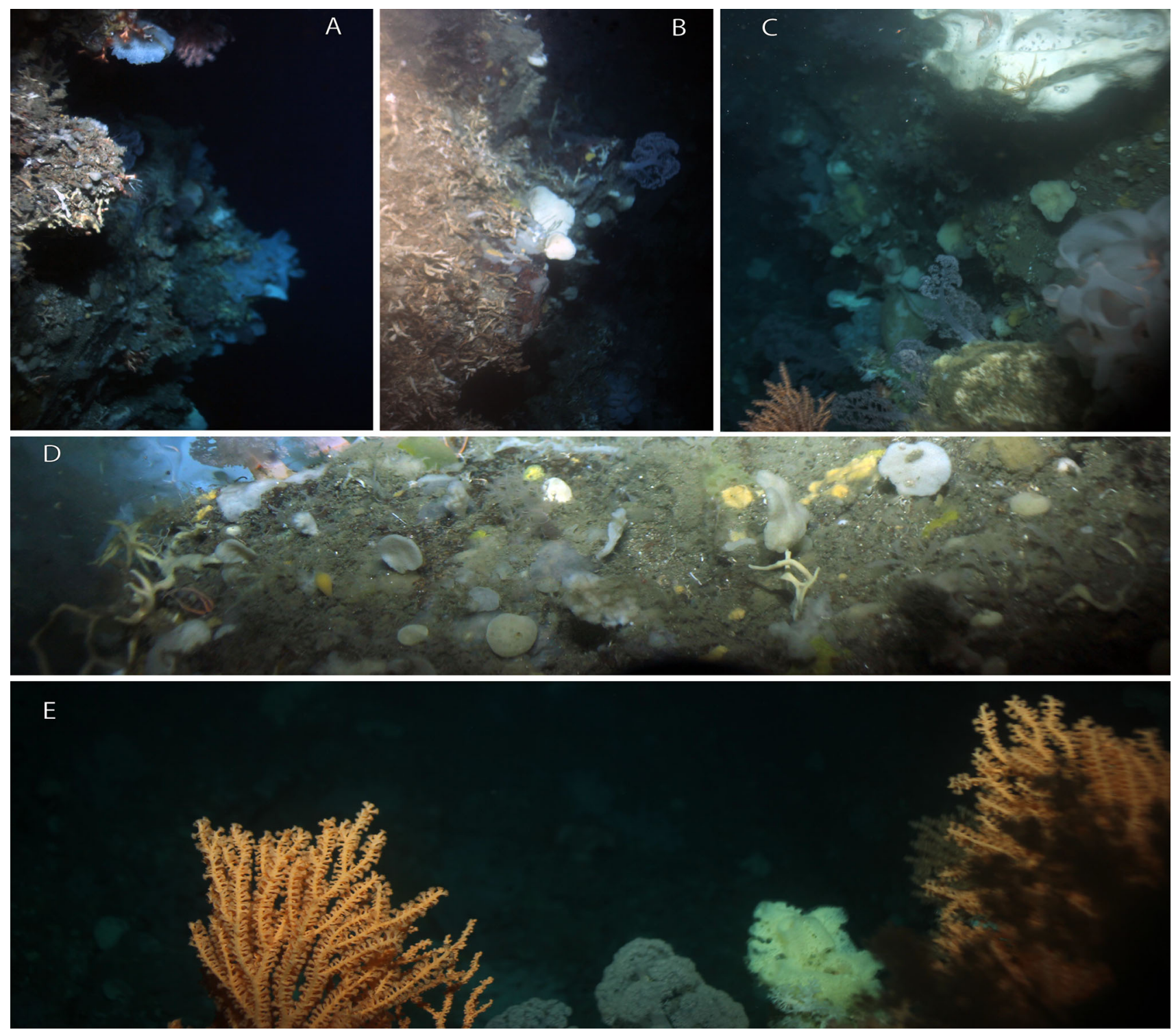

Fig. 11 In situ photographs of the Lophelia pertusa reef and surrounds taken from the Greenland continental slope (CON135, Fig. 3). A, B Living L. pertusa on the steep slope with underlying

the $>30$ species recorded here must be considered a fraction of what really lives on the reef, probably ca. $10 \%$ (Danois 1948; Burdon-Jones and Tambs-Lyche 1960; Jensen and Frederiksen 1992; Mortensen and Fosså 2006). A direct comparison with these studies is biased because in each of the investigations making the most of the material depended on the collection method, handling of the catch and the preservation as well as on the kind of specialists taking part, and these factors differed between investigations. Comparison of species numbers and taxonomic composition of species lists become a very superficial matter because the animal groups, especially major ones as, for example, sponges, hydroids, polychaetes and bryozoans, were not worked up to the same level. Taken bioherm; C, D non-reef habitat on the same transect line that is dominated by sponges; E Primnoa resedaeformis and smaller soft corals (Nephtheidae) from the vicinity of the reef

together, more than 900 species have been recorded from northeast Atlantic L. pertusa reef areas (Rogers 1999). However, the compositions of the associated faunas in geographic areas at some distance from each other are different, with only low numbers of overlapping species (Jensen and Frederiksen 1992). About 300 species were recorded in Norwegian and Faroese reefs and few, if any, are obligate $L$. pertusa reef inhabitants, rather they are local fauna finding suitable living space in the many habitats of the reef (Burdon-Jones and Tambs-Lyche 1960; Jensen and Frederiksen 1992). The fauna found on the Greenland $L$. pertusa site seemed to be dominated by species of northern temperate distribution. Greatest faunal similarity may be with the Faroese reefs, but it should be borne in mind that 
Table 1 List of associated fauna identified from the Lophelia pertusa specimen (Fig. 2) and in situ photographs * collected from southwest Greenland at the reef site (Fig. 3)

\begin{tabular}{|c|c|}
\hline Phylum, class/order & Lowest taxon identified \\
\hline Porifera & $\begin{array}{l}\text { Asconema setubalense* } \\
\text { Forcepia forcipis } \\
\text { Iophon piceus } \\
\text { Hymedesmia } \text { sp. } 1 \\
\text { Hymedesmia } \text { sp. } 2\end{array}$ \\
\hline Cnidaria & $\begin{array}{l}\text { Halecium labrosum } \\
\text { Lafoea dumosa } \\
\text { Bougainvillidae sp. } \\
\text { Paragorgia arborea* } \\
\text { Primnoa resedaeformis* }\end{array}$ \\
\hline $\begin{array}{l}\text { Annelida, Polychaeta (all } \\
\text { heavily fragmented) }\end{array}$ & $\begin{array}{l}\text { Ninoe sp.? } \\
\text { Dorvillidae } \\
\text { Syllidae } \\
\text { Sabellidae } \\
\text { Serpulidae }\end{array}$ \\
\hline Mollusca, Gastropoda & Mohnia simplex \\
\hline Crustacea, Isopoda & $\begin{array}{l}\text { Janira maculosa } \\
\text { Munnidae, probably } 2 \text { species }\end{array}$ \\
\hline Crustacea, Amphipoda & $\begin{array}{l}\text { Caprella rinki } \\
\text { Stegocephalidae sp. } \\
\text { Gitana } \text { cf. rostrata }\end{array}$ \\
\hline Bryozoa & $\begin{array}{l}\text { Exidmonea atlantica } \\
\text { Reteporella beaniana } \\
\text { Disporella hispida } \\
\text { Turbicellipora bathyalis } \\
\text { Turbicellepora boreale } \\
\text { Turbicellepora groenlandica } \\
\text { Entalophoroecia deflexa } \\
\text { Tubulipora aperta }\end{array}$ \\
\hline Echinodermata & $\begin{array}{l}\text { Ophiactis abyssicola } \\
\text { Ophiacantha anomala or O. nodosa } \\
\text { (juvenile specimens) } \\
\text { Gorgonocephalus sp.* }\end{array}$ \\
\hline
\end{tabular}

Icelandic coral reef fauna has not yet been studied. It is expected that the number of faunal taxa associated with the $L$. pertusa reef in Greenland will increase with further sampling efforts.

\section{Future research}

(1) Mapping of the distribution of L. pertusa reefs. Most obvious target areas are parts of the steep slope from Cape Farewell to the sill between the Labrador Basin and Baffin Bay influenced by water of Atlantic origin. Potential reef habitats may also exist in the outer part of some of the so called Atlantic West Greenland fjords.
(2) Age determination of the L. pertusa bioherms. It is to be supposed that the coral spread north when the Atlantic Water began to flow into the area. This might be indicative also for the time of colonization of a large part of the species constituting the associated fauna.

(3) Investigation of the composition of the associated fauna. A crucial question is if the associated fauna is composed of species occurring in other habitats in the area, or if it in some ways represents a specialization.

Acknowledgments We are grateful to the Commanding Officer and the crew of CCGS Martha L. Black for making this discovery possible. We wish to heartily thank the following colleagues for identification: Dr. Nina V. Denisenko, Zoological Museum, St. Petersburgh (Bryozoa), Dr. Danny Eibye-Jacobsen, Natural History Museum of Denmark, Copenhagen (Polychaeta), Dr. Jean Just, Natural History Museum of Denmark, Copenhagen (Crustacea), Dr. Sabine Stöhr, Swedish Museum of Natural history, Stockholm (Ophiuroidea), Dr. Tom Schiøtte, Natural History Museum of Denmark, Copenhagen (Gastropoda) and Dr. Peter Schuchert, Muséum d'Histoire Naturelle, Geneva (Hydroida). We thank Megan Best, Barry MacDonald, Erica Head (Bedford Institute of Oceanography, Dartmouth) and Claude Nozière (Maurice Lamontagne Institute, Quebec) for their assistance in securing and transporting the specimen. We are grateful to Drs. Calvin Campbell and Vlad Kostylev (NRCAN) for the use of the 4KCam and Angus Robertson (NRCAN) for his able deployment of it under difficult conditions. We thank Camille Lirette for his assistance in preparing figures. We thank the Editor of Polar Biology and three independent reviewers for their helpful comments. Funding was through the International Governance Strategy Program of the Canadian Department of Fisheries and Oceans to EK.

Open Access This article is distributed under the terms of the Creative Commons Attribution 4.0 International License (http://crea tivecommons.org/licenses/by/4.0/), which permits unrestricted use, distribution, and reproduction in any medium, provided you give appropriate credit to the original author(s) and the source, provide a link to the Creative Commons license, and indicate if changes were made.

\section{References}

Alander H (1942) Sponges from the Swedish west-coast and adjacent waters. Henrik Struves Boktryckeri, Göteborg

Beazley LI, Kenchington EL, Murillo FJ, Sacau M (2013) Deep-sea sponge grounds enhance diversity and abundance of epibenthic megafauna in the Northwest Atlantic. ICES J Mar Sci 70:1471-1490

Beuck L, Vertino A, Stepina E, Karolzak M, Pfannkuche O (2007) Skeletal response of Lophelia pertusa (Scleractinia) to bioeroding sponge infestation visualized with micro-computed tomography. Facies 53:157-176

Brooke S, Ross SW, Bane JM, Seim HE, Young CM (2013) Temperature tolerance of the deep-sea coral Lopehlia pertusa from the southeastern United States. Deep-Sea Res II 92:240-248

Buhl-Mortensen L, Olafsdottir SH, Buhl-Mortensen P, Burgos JM, Ragnarsson SA (2014) Distribution of nine cold-water coral species (Scleratinia and Gorgonacea) in the cold temperate North 
Atlantic: effects of bathymetry and hydrography. Hydrobiologia. doi:10.1007/s10750-014-2116-x

Burdon-Jones C, Tambs-Lyche H (1960) Observations on the fauna of the North Brattholmen stone-coral reef near Bergen. Årbok for Universitetet i Bergen. Mat Narurv Serie 1960:1-24

Carney RS (1989) Examining the relationships between organic carbon flux and deep-sea deposit feeding. In: Lopez G, Taghon G, Levinton J (eds) Ecology of marine deposit feeders. SpringerVerlag, New York, pp 24-58

Carney RS (2005) Zonation of deep biota on continental margins. Oceanogr Mar Biol Ann Rev 43:211-278

Clarke RA (1984) Transport through the Cape Farewell-Flemish Cap Section. Rapports et Procès-verbaux des Réunions/Conseil Permanent International pour l'exploration de la Mer 185:120-130

Copley J, Tyler PA, Sheader M, Murton J, German CR (1996) Megafauna from sublittoral to abyssal depths along the MidAtlantic Ridge south of Iceland. Acta Oecol 19:549-559

Davies AJ, Wisshak M, Orr JC, Roberts JM (2008) Predicting suitable habitat for the cold-water coral Lophelia pertusa (Scleractinia). Deep-Sea Res I 55:1048-1062

Denisenko NV (2016) Two new species of the genus Turbicellepoa Ryland, 1963 (Bryozoa: Celleporidae) found on Lophelia coral from the Greenland slope. Zootaxa 4066:177-182

Dodds LA, Roberts JM, Taylor AC, Marubini F (2007) Metabolic tolerance of the cold-water coral Lophelia pertusa (Scleractinia) to temperature and dissolved oxygen change. J Exp Mar Biol Ecol 349:205-214

Dullo WC, Flögel S, Rüggeberg A (2008) Cold-water coral growth in relation to the hydrography of the Celtic and Nordic European continental margin. Mar Ecol Prog Ser 371:165-176

Fosså JH, Alvsvåg J (2003) Kartleggning og overvåkning av korallrev. Fisken og Havet. Special Issue 2:62-67

Freiwald A, Fosså JH, Graham A, Koslow T, Roberts JM (2004) Cold-water coral reefs. UNEP-WCMC, Cambridge

Hansen KB (1962) Bryozoa: the Godthaab Expedition 1928. Meddeleser om Grønland 81:1-74

ICES (2008) Report of the ICES-NAFO Joint Working Group on Deep Water Ecology (WGDEC), 10-14 March 2008, Copenhagen, Denmark. ICES CM 2008/ACOM:45

Jensen A, Frederiksen R (1992) The fauna associated with the bankforming deepwater coral Lophelia pertusa (Scleractinaria) on the Faroe shelf. Sarsia 77:53-69

Jørgensen OA, Tendal OS, Arboe NH (2013) Preliminary mapping of the distribution of corals observed off West Greenland as inferred from bottom trawl surveys 2010-2012. NAFO SCR Doc. 13/007. Northwest Atlantic Fisheries Organization Serial No N6156

Jungersen H (1915) Alcyonaria, Anthipatharia og Madreporaria. Conspectus Faunae Groenlandicae. Meddeleser om Grønland 23, C. A. Reitzels Forlag, Københaven

Keike D, Yashayaev I (2015) Studies of Labrador Sea Water formation and variability in the subpolar North Atlantic in the light of international partnership collaboration. Progr Oceanogr 132:220-232

Kramp PL (1932) The Godthaab Expedition 1928 Alcyonaria, Antipatharia, and Madreporaria. Meddelelser om Grønland Bd 79(4): $1-20$

Kuijpers A, Dalhoff F, Brandt MP, Hümbs P, Schott T, Zotova A (2007) Giant iceberg plow marks at more than $1 \mathrm{~km}$ water depth offshore West Greenland. Mar Geol 246:60-64

Lazier J, Hendry R, Clarke A, Yashayaev I, Rhines P (2002) Convection and restratification in the Labrador Sea, 1990-2000. Deep-Sea Res I 49:1819-1835

Le Danois E (1948) Les profondeurs de la mer. Trois ans de recherche sur la faune sous-marin au large du côtes du France. Paris, Payot

Madsen FJ (1944) Octocorallia (Stolonifera, Telestacea, Xeniidea, Alcyonacea, Gorgonacea). Dan Ingolf-Exped V 13:1-65
Mangor K, Zorn R (1983) Iceberg conditions offshore Greenland. Iceberg Res 4:4-20

Moore GWK, Renfrew IA (2005) Tip jets and barrier winds: a QuikSCAT climatology of high wind speed events around Greenland. J Clim 18:3713-3725

Mortensen PB, Fosså JH (2006) Species diversity and spatial distribution of invertebrates on Lophelia reefs in Norway. In: Proceedings of the 10th international coral reef symposium. Okinawa, Japan, pp 1849-1868

Mueller CE, Lundälv T, Middelburg JJ, van Oevelen D (2013) The symbiosis between Lophelia pertusa and Eunice norvegica stimulates coral calcification and worm assimilation. PLoS One 8:e58660. doi:10.1371/journal.pone.0058660

Myers PG, Ribergaard MH (2013) Warming of the Polar Water Layer in Disko Bay and potential impact on Jakobshavn Isbrae. J Phys Oceanogr 43:2629-2640

Ribergaard MH (2012) Oceanographic Investigations off West Greenland 2011. NAFO Scientific Council Documents, 12/002

Rogers AD (1999) The biology of Lophelia pertusa (Linnaeus, 1758) and other deep-water reef-forming corals and impacts from human activities. Int Rev Hydrobiol 84:315-406

Rogers AD, Baco A, Griffiths H, Hart T, Hall-Spencer JM (2007) Corals on seamounts. In: Pither TJ, Morato T, Hart PJB, Clark MR, Haggan N, Santos RS (eds) Seamounts: ecology, fisheries and conservation. Wiley-Blackwell Publishing Ltd., Oxford, pp 141-169

Schröder-Ritzrau A, Freiwald A, Mangini A (2005) U/Th-dating of deep-water corals from the eastern North Atlantic and western Mediterranean. In: Freiwald A, Roberts JM (eds) Coldwater corals and ecosystems. Springer-Verlag, Berlin, pp 157-172

Schuchert P (2001) Hydroids of Greenland and Iceland (Cnidaria, Hydrozoa). Bioscience 53:1-184

Stephensen K (1933) Amphipoda. The Godthaab Expedition. Meddelelser om Grønland 79:1-88

Sulak KJ, Brooks RA, Luke KE, Norem AD, Randall M, Quaid AJ, Yeargin GE, Miller JM, Harden WM, Caruso JH, Ross SW (2007) Demersal fishes associated with Lophelia pertusa coral and hard-substrate biotopes on the continental slope, northern Gulf of Mexico. In: George RY, Cairns SD (eds) Conservation and adaptive management of seamount and deep-sea coral ecosystems. Rosenstiel School of Marine and Atmospheric Science, University of Miami, Miami, pp 65-92

Tendal OS (1992) The North Atlantic distribution of the octocoral Paragorgia arborea (L., 1758) (Cnidaria, Anthozoa). Sarsia 77:213-217

Tendal OS, Jørgensbye HIØ, Kenchington E, Yashayaev I, Best M (2013) Greenland's first living deep-water coral reef. ICES Insight 50:14-17

van Soest RWM, Beglinger EJ (2009) New bioeroding sponges from Mingulay coldwater reefs, north-west Scotland. J Mar Biol Assoc UK 89:329-335

van Soest RWM, Lavaleye MSS (2005) Diversity and abundance in bathyal coral reefs of Rockall Bank, NE Atlantic, from boxcore samples. Mar Biol Res 1:338-349

Yashayaev I (2007) Hydrographic changes in the Labrador Sea, 1960-2005. Progr Oceanogr 73:242-276

Yashayaev I, Dickson RR (2008) Transformation and fate of overflows in the northern North Atlantic. In: Dickson RR, Meincke J, Rhines $P$ (eds) Arctic-subarctic ocean fluxes: defining the role of the northern seas in climate. Springer, Dordrecht, pp 505-526

Yashayaev I, Loder JW (2009) Enhanced production of Labrador Sea Water in 2008. Geophys Res Lett 36:L01606. doi:10.1029/ 2008GL036162

Yashayaev I, Seidov D (2015) The role of the Atlantic Water in multidecadal ocean variability in the Nordic and Barents Seas. Progr Oceanogr. doi:10.1016/j.pocean.2014.11.009 
Yashayaev IM, Zveryaev II (2001) Climate of the seasonal cycle in the North Pacific and the North Atlantic Oceans. Int J Climat 21:401-417

Yashayaev I, Bersch M, van Aken HM (2007) Spreading of the Labrador Sea Water to the Irminger and Iceland basins. Geophys Res Lett 34:1-8
Zibrowius H (1980) Les scleractinaires de la Mediterranée et de l'Atlantique nord-oriental. Memoires de L'Institut Oceanographique, Monaco 11:125-130 